\title{
A nova lei de educação superior: fortalecimento do setor público e regulação do privado/mercantil ou continuidade da privatização e mercantilização do público?
}

\author{
João dos Reis Silva Júnior \\ Universidade Federal de São Carlos, Departamento de Educação

\section{Valdemar Sguissardi} \\ Universidade Metodista de Piracicaba, Programa de Pós-Graduação em Educação
}

\section{Introdução}

O tema da reforma universitária, no Brasil ou alhures, deve ser estudado como um processo de continuidades e rupturas na área da educação. $\mathrm{O}$ exame das reformas da educação superior, no século XX e limiar do século XXI, conduz à conclusão de que se trata de mudanças no ordenamento jurídico-educacional que dão seguimento às modificações dos projetos políticos para o país, numa efetiva síntese entre interesses nacionais e internacionais.

Uma lei não contém toda a reforma. Uma reforma educacional ou da educação superior raramente se traduz em uma única lei, por mais abrangente que ela seja. A nova lei de educação superior (ou a nova lei da reforma universitária), cujo anteprojeto se encontra em discussão, visa a atualizar as definições, a forma de organização e as condições de funcionamento do sistema, a validade de seus diplomas e sua adequação às normas constitucionais e às supostas necessidades do desenvolvimento do país no setor. Uma lei assim, entretanto, não é o começo nem o fim da reforma. Ela deve pressupor a existência de ou- tros dispositivos legais antigos e recentes que prescrevem normas para diferentes campos correlatos e complementares que, em seu conjunto, configuram o amplo campo da educação superior, entendido como o campo da associação ensino, pesquisa e extensão e suas interfaces com a sociedade civil, da qual faz parte, e com os interesses do mercado, em que ocupa lugar de destaque a relação público/privado, ou a contraposição ensino superior como bem público ou bem econômico.

A reforma da educação superior tem sido objeto da ação político-administrativa de governos anteriores, especialmente no octênio de Fernando Henrique Cardoso (FHC), tanto pela via legislativa, quanto por medidas ostensivas de restrição do crescimento do setor público federal e de incentivo à expansão do setor privado; tanto pela negação da autonomia, pelo congelamento salarial, pela redução de vagas docentes e de funcionários e pelo drástico corte do financiamento das instituições federais de ensino superior, quanto pela adoção de um sistema de avaliação da educação superior contábil e definidor de ranking interinstitucional, ao gosto da mídia e do mercado. 
No primeiro biênio do atual mandato presidencial destacam-se quatro medidas legais, referidas ou não no anteprojeto de lei (como se verá adiante), que se constituem em importantes precedentes para esse anteprojeto, que podem ancorá-lo em seus objetivos ou negá-lo parcial ou totalmente. Esses dispositivos legais, com menos de um ano de vigência, são: a) lei $\mathrm{n}^{\circ}$ 10.861, de 14/4/2004, que cria o Sistema Nacional de Avaliação da Educação Superior (SINAES), regulamentada pela portaria do Ministério da Educação (MEC) no 2.051, de 9/7/2004; b) lei no 10.973, de 2/ 12/2004, que dispõe sobre incentivos à inovação e à pesquisa científica e tecnológica no ambiente produtivo e dá outras providências; c) lei no 11.079 , de 30/ 12/2004, que institui normas gerais para licitação e contratação de parceria público/privado (PPP) no âmbito da administração pública; d) lei no 11.096 , de 13/ 1/2005 (Medida Provisória - MP n² 213, de 10/9/ 2004), que institui o Programa Universidade para Todos (PROUNI), regula a atuação de entidades beneficentes de assistência social no ensino superior, altera a lei $\mathrm{n}^{\circ} 10.891$, de 9/7/2004, e dá outras providências.

Por essas razões, serão aqui expostos alguns elementos históricos, conceituais e de princípios, para um exame preliminar do anteprojeto de lei da educação superior, na versão de 6 de dezembro de 2004, como parte e decorrência do processo de transformação da educação superior no Brasil. Esse processo tem se caracterizado por duplo movimento de alternância na valorização das esferas pública e privada, dandose ora a restrição de uma e a expansão de outra, ora vice-versa, mas mantendo-se com continuidade o crescente caráter mercantil das instituições de educação superior, com graves conseqüências para sua autonomia e seu financiamento, assim como para a organização do Sistema Federal da Educação Superior; enfim, para sua identidade institucional.

Este artigo apresenta certo grau de complexidade porque envolve a recente história de muitas reformas educacionais do nível superior, no contexto latino-americano e mesmo mundial, e diante de eventos e constrangimentos políticos recentes em nosso país. Além disso, refletir sobre a educação superior brasi- leira e sua expressão no cotidiano da estrutura, organização e gestão das instituições de ensino superior revela-se tarefa bastante arriscada diante das recentes reformas institucionais ocorridas no governo FHC, especialmente as do aparelho do Estado e da educação superior, e, mais remotamente, a reforma universitária concretizada durante a ditadura militar.

Isso posto, impõe-se preliminarmente tornar claros o lugar, os fins e as metas da educação superior no governo de Luiz Inácio Lula da Silva, considerando a herança política advinda dos governos militares e dos últimos governos civis, assim como sua orientação político-social, anunciada na Carta ao povo brasileiro, ${ }^{1}$ que se traduziu também pelo Pacto pela cidada$n i a,{ }^{2}$ no contexto atual da universalização do capita-

${ }^{1}$ Esse documento, datado de 22/7/2002, contendo dez compromissos básicos do futuro governo Lula, romperia com o pensamento tradicional petista e inauguraria "uma perspectiva mais técnica da condução da política econômica, objetivando a criação de um ambiente seguro para os investimentos produtivos. Não há, assim, qualquer sugestão de alteração profunda da estrutura produtiva, o que inclui a estrutura fundiária do país, a adoção de impostos progressivos, discriminação dos investimentos públicos a partir de critérios sociais. [...] Em suma, teria nascido um novo paradigma econômico petista (ou lulista) a partir de então" (Ricci, 2005). Nessa carta, alguns compromissos se destacam: a) plano de governo que se sustente na redução da vulnerabilidade externa, em reformas estruturais (tributária, agrária, previdenciária, trabalhista), no combate à forme, à insegurança pública e ao déficit habitacional; b) governabilidade via coalizão nacional, que implica processos exaustivos de negociação, alianças, pacto social e crescimento com estabilidade; c) respeito aos contratos e obrigações do país, não ao calote na dívida externa e política austera de controle do endividamento público; d) segurança dos investidores não-especulativos [segundo Ricci (2005): “O discurso é nítido: a estabilidade do mercado seria perseguida a todo custo"]; e) controle inflacionário; f) equilíbrio fiscal; g) superávit primário, visando à capacidade de honrar compromissos. Para maiores detalhes, ver Ricci (2005).

2 "No momento em que o pacto social volta à agenda do país, recordo-me da viagem que organizei para Israel, em 1997, pelo 
lismo - que se dá especialmente pelo deslocamento do capital para esferas outrora organizadas, ainda que parcialmente, segundo a lógica pública -, contexto em que se intensifica a dimensão estatal mercantil própria do Estado moderno. Portanto, além de com tais cuidados, a análise desse anteprojeto de lei deve ser feita integrada a (e como decorrência de) outras realidades ou medidas que reorganizam a nova forma histórica do Brasil, tais como a atual reestruturação produtiva, a presença do terceiro setor, a nova política econômica e a cultura política que dá sustentação ao que tem sido alardeado como pacto social, além da reforma do Estado, das leis da parceria público/privado, dos fundos setoriais, da inovação tecnológica, das diretrizes curriculares para a graduação, do paradigma de avaliação e certificação educacionais de todos níveis e modalidades de ensino (da educação infantil à pós-graduação), do financiamento do ensino superior e da indução à pesquisa mediante estímulos financeiros, da organização do sistema federal de ensino superior e das formas de organização e gestão das instituições de educação superior.

Se neste artigo não forem enfocadas essas relações, existentes nessa fase de mudanças da educação superior como um momento específico e democrático de reforma, far-se-á uma leitura pouco crítica do que há cerca de quinze anos se vem construindo e apresentando na estética jurídico-formal que confi-

Pensamento Nacional das Bases Empresariais (PNBE). Reunimos, de forma absolutamente inimaginável para a época, dez empresários, o presidente e o secretário-geral da Central Única dos Trabalhadores (CUT), Jair Meneguelli e Gilmar Carneiro, e Luiz Antonio de Medeiros, presidente de uma organização sindical oponente. Fomos para conhecer o pacto social israelense que acabou com a inflação de $30 \%$ ao mês. Lembro-me do papel fundamental de Lula, que, apostando desde aquela época na construção de um pacto social, empenhou-se comigo para quebrar resistências e preconceitos. [...] Portanto, quando falamos de pacto social, falamos de um processo permanente que envolve toda a sociedade numa série de negociações e acordos sobre diversos assuntos que interessam à comunidade.” (Grajew, 2002) gura o Estado e, no caso, a educação superior; isto é, sem adequada apreensão do conteúdo histórico que desvela as entranhas do pacto social do hoje chamado governo popular e democrático.

\section{Dados contextuais das mudanças da educação superior no Brasil: um olhar próximo}

O governo FHC teve no centro de seu projeto político a construção da cidadania. Tornado público pelo discurso de seus mentores e arautos nos grandes espaços e tempos da mídia, esse projeto alardeava a construção do novo cidadão brasileiro a erigir-se sobre os pilares do modelo de competência e empregabilidade e em meio à intensa mudança institucional e construção de nova organização social nos moldes do novo paradigma de Estado, cuja racionalidade se fundava em crescentes e inegáveis valores mercantis (Sguissardi \& Silva Jr., 2001).

Tratava-se, sem dúvida, de um projeto político muito convincente, não fosse limitado pela conjuntura mundial e brasileira; no caso doméstico, com os seguintes traços acentuados na segunda metade dos anos de 1990:

a) a adoção no país do novo paradigma de organização das corporações mundiais;

b) a desnacionalização da economia;

c) a desindustrialização;

d) a transformação da estrutura do mercado de trabalho, incluindo sua terceirização e precarização, e flexibilização das relações trabalhistas;

e) a reforma do Estado e a restrição da esfera pública e a ampliação da privada;

f) o enfraquecimento das instituições políticas de mediação entre a sociedade civil e o Estado, especialmente dos sindicatos e partidos políticos;

g) o trânsito da sociedade do emprego para a sociedade do trabalho, isto é, a tendência ao desaparecimento dos direitos sociais do trabalho;

h) a transferência de deveres e responsabilidades do Estado e do direito social e subjetivo do cidadão para a sociedade civil. 
O governo FHC, parecendo atualizar a tese contida em obra de seu titular (Cardoso, 1993), colocou em prática uma política ajustada aos ditames do capital financeiro internacional, preocupando-se apenas tangencialmente com o fortalecimento do capital industrial (produtivo) brasileiro. Em contrapartida, diante da desmobilização da sociedade civil verificada nos anos de de 1980 e início dos anos de 1990, governou o país considerando apenas parcialmente as tradicionais formas de mobilização popular e apoiando-se ostensivamente nas organizações não-governamentais (ONGs), cujo fortalecimento sempre incentivou. Concomitantemente se consolidou o hiperpresidencialismo como forma de governo, isto é, recrudesceu a hipertrofia do Poder Executivo em detrimento dos demais poderes da República. Com isso fragilizou-se o capital nacional, destacadamente a indústria; redesenhou-se a sociedade civil, instituindo-se as ONGs como interlocutoras preferenciais do governo, transferindo-se os deveres do Estado e os direitos sociais subjetivos do cidadão para a sociedade civil, porém sob o controle centralizado do Poder Executivo federal. Produzia-se, assim, um novo paradigma de políticas públicas: o das políticas públicas de oferta, a serem executadas na sociedade civil, em geral pelas ONGs. Somando-se às reformas institucionais, essas mudanças redesenharam a sociabilidade do país, criando condições para a produção de um novo paradigma político orientado pela instrumentalidade, a adaptação e a busca de consenso. ${ }^{3}$ Tal quadro se completa com a submissão consentida da ação governamental às agências multilaterais, ilustrada pelas altíssimas taxas de juros básicos (Sistema Especial de Liquidação e Custódia - SELIC) e de superávit primário (4,25\% do Produto Interno Bruto PIB); pelos R $\$ 150$ bilhões pagos de juros da dívida externa em 2003, ao preço da estagnação do PIB nacional; pela continuidade da concentração de renda; pela retração de quase todos os setores das políticas

${ }^{3}$ Traços político-administrativos assumidos pelo atual governo desde a Carta ao povo brasileiro e o pacto social decorrente. sociais: saúde, educação, reforma agrária, previdência etc. O aumento do PIB em 2004 (5,2\%, em torno da média mundial), para o que contribuíram especialmente o agronegócio e o setor industrial, na esteira das exportações facilitadas por uma conjuntura de trocas internacionais extremamente favorável e com produtos de baixa agregação de valor, não garante por si só nem a melhor distribuição de renda, nem a recuperação do atraso verificado nas políticas públicas nos últimos anos.

Esses dados têm um significado relevante: mostram a hipertrofia da dimensão estatal mercantil, produzida pelas novas políticas que se constituem no cerne da atual racionalidade histórica do capitalismo brasileiro e acentuam a mercantilização da democracia liberal neste país, o que nega os pilares centrais da ideologia liberal clássica.

Luiz Inácio Lula da Silva assumiu a presidência da República do Brasil nesse contexto, em 2002, com grande maioria de votos, confiança popular e cética expectativa das agências multilaterais, tendo como plataforma eleitoral o pacto social anunciado na Carta ao povo brasileiro. Neste quadro conjuntural, convém perguntar: como as continuidades e rupturas ensejadas por essa proposta política ajudam a compreender a vitória da coligação em torno de Lula na mais recente (e importante) eleição presidencial brasileira? Como auxiliam na apreensão da lógica que move as políticas atuais para a educação superior, parcialmente representadas pelo anteprojeto de lei ora em exame?

Dada sua trajetória pessoal, de sindicalista a presidente da República, Lula sempre esteve próximo da sociedade civil organizada, na qual despontavam movimentos sociais que visavam a estabelecer condições para o paradigma de políticas públicas afinadas com efetivas demandas sociais. Demarca essa proximidade seu itinerário e liderança inconteste, que vai da emergência do "novo sindicalismo" e criação do Partido dos Trabalhadores (PT), no final dos anos de 1970 e início dos anos de 1980, até pelo menos 1998, data da derrota de Lula, em primeiro turno, para o candidato à reeleição Fernando Henrique Cardoso. A 
avaliação desse fato (terceira derrota consecutiva) teria conduzido o comando do PT, sob a liderança de seu principal expoente, a adotar visão e ações muito mais pragmáticas no jogo político-eleitoral brasileiro, como indicam o teor da Carta ao povo brasileiro em aproximação com o Pensamento Nacional das Bases Empresariais (PNBE). ${ }^{4}$

Qual seria, então, a nova equação política desse partido e coligação que garantiria a significativa vitória nas urnas em 2002? Segundo análises muito consistentes dessa carta e de outras manifestações e medidas pertinentes, seria o compromisso de continuidade dos mesmos padrões político-administrativos adotados pelo governo anterior em relação ao capital financeiro internacional - vistos como pressupostos da governabilidade e do fim da vulnerabilidade externa do país, além da recuperação dos escandalosos índices de desigualdade social. Nenhuma proposta de alteração "revolucionária" das estruturas produtiva, fundiária ou industrial. Ao contrário, a afirmação do compromisso de estrito respeito a contratos e obrigações do país com a comunidade financeira internacional, via controle do endividamento público, aumento do superávit primário e busca do equilíbrio fiscal.

A mais significativa ruptura com o modus operandi do governo anterior, ainda que contando com uma sociedade civil redesenhada, revelava-se na maior disposição para o diálogo/negociação ${ }^{5}$ que Lula é capaz de demonstrar, por sua história, tendo em vista garantir a governabilidade que por muito tempo esteve sob forte suspeita. Esse esforço em busca do diálogo revela-se de forma clara no movimento de aproximação com o capital produtivo industrial nacional, já articulado com o capital financeiro nacional e internacional.

As perspectivas de continuidade político-administrativa e a ausência de efetiva ruptura com as estruturas vigentes acabaram sendo aceitas pela maio-

\footnotetext{
${ }^{4}$ Conforme notas 1 e 2.
}

${ }^{5}$ Que nem sempre trouxeram bons resultados para os aliados históricos; como exemplo, a reforma da Previdência. ria da população, por hipótese, por não se esperar que isso fosse além de uma estratégia eleitoral ou porque se aceitou como verdadeira a explicação de que somente por essa via seria possível reverter o quadro de submissão da economia brasileira ao capital financeiro nacional e internacional, nos moldes da teoria monetarista adotada pela equipe econômica anterior, concorde com os principais organismos financeiros internacionais e em uníssono com o quadro da universalização do capitalismo.

Seriam essas as bases do pacto social da coligação que conduziu Lula à presidência, e que apresentam sérias consequiências para a política de ciência, tecnologia e inovação tecnológica e para a esfera educacional, especialmente para a educação superior. Nesse nível, como no macroeconômico, nenhuma grande ruptura; antes, a quase continuidade das teses defendidas e postas em prática pelo governo anterior, mais uma vez no mesmo diapasão das teses defendidas pelos organismos financeiros multilaterais, mas de incisiva intervenção no campo das políticas sociais públicas dos países, seja do centro seja da periferia ou semiperiferia. Teses como a de que, na contraposição estatal/privado, este segundo pólo seria mais condizente com os novos tempos e com a busca da justiça social, escamoteando-se a verdadeira contraposição a ser considerada, isto é, o interesse ou bem público versus interesse ou bem privado/mercantil, e impondo-se, portanto, a necessidade de diluição das fronteiras público/privado; de que o retorno individual e social dos gastos públicos com educação superior seria muito menor do que o dos gastos com a educação básica; de que a educação superior seria antes um bem privado e que os gastos públicos na educação superior beneficiariam fundamentalmente as elites, não se prestando à melhor distribuição de renda, à equidade e à justiça social; de que haveria maior eficiência gerencial dos recursos públicos se entregues ao gerenciamento de empresas privadas; de que o ensino superior deveria ser, cada dia mais, um espaço da iniciativa privada, e não do Estado, devendo este preocupar-se menos com a criação e manutenção de instituições de ensino superior 
do que com a regulação, controle e prestação de contas das instituições de ensino superior públicas e privadas, com e sem fins lucrativos; de que, em lugar do paradigma científico-acadêmico clássico, da associação ensino e pesquisa ou da prioridade da ciência básica versus ciência aplicada, deve hoje prevalecer a ciência dirigida pela economia, além da neoprofissionalização do sistema com base no imediatismo pragmático e eficientista. Enfim, teses como essas, entre outras, parecem continuar a ser defendidas e implementadas quando se examina mais detidamente o significado dos dispositivos legais recentemente promulgados, como as acima citadas leis da parceria público/privado, do PROUNI e da inovação tecnológica.

Onde, no plano político-administrativo mais geral, parece haver uma ruptura mais significativa é exatamente na disposição ao diálogo/negociação nesse setor das políticas públicas, tendo como resultado uma sensibilidade maior do que a ocorrida no octênio governamental anterior para o diagnóstico que indica a acelerada privatização/mercantilização do sistema e a necessidade de controlar, por um lado, a expansão desenfreada das empresas de ensino e, por outro, a qualidade mínima dos serviços prestados.

Carlos Vogt, presidente da Fundação de Apoio à Pesquisa do Estado de São Paulo (FAPESP), renomada agência de financiamento à pesquisa, especialmente a vinculada à ciência, tecnologia e inovação tecnológica, indicava, em encarte especial da Revista Pesquisa de março de 2003, a universalização do capitalismo, seu inerente pragmatismo e a mercantilização da democracia liberal como panos-de-fundo das recentes mudanças educacionais fundadas no paradigma economicista. Concluía afirmando que, assim organizada e "sem propósitos culturais, morais e intelectuais, a educação perde seu caráter civilizatório e reduz-se a mero expediente de oportunidade, $e$ mesmo de oportunismo social na competição desenfreada pelas vagas do mercado" (Vogt, 2003, p. 59, grifos nossos). É relevante nesse texto do presidente da FAPESP a importância da ciência, da cultura e da educação e das instituições que as produzem, parecendo existir total identidade com o que seria preten- dido pelo projeto político do governo Lula para o Brasil. Levando-se em conta, entretanto, a articulação política oficial entre capital nacional e trabalho, que busca produzir uma cultura de negociação em direção ao consenso, do qual emergiria o crescimento econômico e maior cacife para o confronto com o capital financeiro nacional e internacional, as assertivas tornam-se pólos opostos de uma escamoteada contradição.

Oficialmente, a produção da ciência, da tecnologia e da inovação tecnológica é posta como centro da dinâmica do crescimento econômico, mas, ao mesmo tempo, todo sistema educacional é subordinado à economia, por mediação das políticas de ciência, tecnologia e inovação tecnológica, enquanto a cultura e a educação, elementos civilizadores, são postas em segundo plano, seja por força das alianças eleitorais, de um lado, seja pelo jugo do capital financeiro internacional articulado ao capital produtivo, de outro, como já pode ser antevisto na Carta ao povo brasileiro.

Há nesse movimento uma forma de atualização da teoria do capital humano, com fortes marcas de neopragmatismo na formação humana pretendida nessas complexas relações. Isso mostra, desde logo, alguns inegáveis traços das políticas públicas no campo da pesquisa no Brasil: maior aplicação de recursos em investigações com resultados imediatos e que conduziriam à mais eficaz aplicação dos recursos voltados para o fortalecimento do capital nacional industrial e agropecuário exportador, investimento que privilegiaria, assim, as "áreas duras" em detrimento das ciências humanas, dentre elas a educação. Seriam exigidas, também, do Sistema Federal da Educação Superior, em termos de formação profissional, respostas muito mais eficazes e rápidas do que as anteriormente dadas às supostas exigências da competitividade no mercado mundial, em um contexto de transferência dessa responsabilidade do Estado para a sociedade civil. Em contrapartida, esses traços de que se revestiria a educação superior brasileira atual tenderiam a afetar todas as áreas do conhecimento, independentemente de suas especificidades, definindo como vilã da história as ciências humanas, com des- 
taque para a educação, acentuadamente em seu nível superior.

\section{Dados contextuais das mudanças da educação superior no Brasil: um olhar distante}

A história recente do Brasil é permeada por freqüentes continuidades e rupturas, representadas por alterações na estrutura do Estado, na sociedade civil e na constituição do cidadão brasileiro. Múltiplas reformas institucionais realizaram-se da década de 1950 até os primeiros anos do século XXI. Em geral com origem no Estado, visavam a mudanças nos múltiplos processos de construção da sociabilidade humana, buscando torná-la adequada à forma histórica assumida pelo país, para o que concorria de forma profunda a educação, no nosso caso especialmente e nesse período, a educação superior.

O golpe militar de 1964 concretizou-se como o resultado de contradição entre o econômico e o político; contradição entre um processo socioeconômico que conduzia à internacionalização da economia brasileira e uma ideologia nacionalista da maioria da "classe" política adepta do nacional-desenvolvimentismo: parte do Partido Trabalhista Brasileiro (PTB), do Partido Social Democrático (PSD) e de setores apartidários. O golpe militar significou, portanto, uma ruptura política para a continuidade socioeconômica, impondo drásticas modificações nas estruturas sociais por meio de processos e métodos coercitivos, com vista em profundas transformações superestruturais.

Nesse contexto, no plano educacional o governo militar-autoritário procurou aumentar a produtividade das escolas públicas com base na adoção de princípios da administração empresarial, além de, desde o início, apontar para a privatização educacional. Procurava-se edificar um sistema federal de educação superior que contribuísse para a consolidação da segunda revolução industrial a realizar-se no país. Isso se dava via decretos-lei, com o patrocínio de diversos acordos firmados entre o MEC e a United States Agency for International Development (USAID). Foi sob tais auspícios que se impôs a denominada refor- ma universitária (lei $\mathrm{n}^{\circ} 5.540 / 68$ ), instituidora do princípio da indissociabilidade entre ensino, pesquisa e extensão, dentre outras razões, para fortalecer o formato institucional da universidade e subsidiar o capital industrial nacional, bem como a reforma do ensino de $1^{\circ}$ e $2^{\circ}$ graus (lei $n^{\circ} 5.692 / 71$ ), que, num ímpeto legisferante, procurou tornar o ensino médio obrigatoriamente profissionalizante, com os objetivos de preparar mão-de-obra para o sistema de ciência e tecnologia que se formava e sustentar o capital industrial nacional, além de conter o acesso à educação superior.

Entretanto, a megalomania militar, expressa no projeto político do Brasil potência, nos anos de 1970, revelou, no devido tempo, seu pesado rol de conseqüências. Quando se fez presente no país a falta de poupança nacional, conjugada ao colapso do projeto político da socialdemocracia em âmbito internacional, e adveio, sombrio, o crepúsculo do milagre econômico, colocou-se a potência da crise social iminente; crise politizada, com a redemocratização, a partir dos anos de 1980, pelo processo de transição do poder político das mãos dos militares para as dos civis, e de um regime ditatorial para uma quase democracia.

A contradição entre, de um lado, um profundo déficit social e produtivo e, de outro, a redemocratização do poder, redundou no fenômeno da politização da crise econômica, fato que enfraqueceu os movimentos sociais, as instituições e organizações políticas de mediação entre o Estado e a sociedade civil, e possibilitou o ajuste socioeconômico e político do início dos anos de 1990. Esse ajuste correspondeu à necessidade de superação da crise capitalista motivada pelo declínio da socialdemocracia, por algumas décadas do século XX vigente de forma moderada nos Estados Unidos e em alguns países da América Latina que desenvolveram o projeto nacional-desenvolvimentista, e mais acentuada em alguns países da Europa. Em contrapartida, a reconfiguração da educação superior brasileira, segundo as diretrizes e normas da lei $\mathrm{n}^{\circ} 5.540 / 68$, alimentou o sistema industrial, com a contribuição das "áreas duras", até o 
momento da "ciranda financeira" do governo Sarney (1984-1989). Mas, em relação às ciências humanas, esse formato universitário e de pesquisa possibilitou, contraditoriamente, grande número de estudos que mostraram a situação catastrófica em que os governos militar-autoritários colocavam o Brasil. Alimentou igualmente muitos dos movimentos sociais fortalecidos nos anos de 1980, mas que assumiram novo posicionamento político, de viés neopragmático, na forma das ONGs ou, de modo mais amplo, quando da emergência do terceiro setor, nos anos de 1990.

Esse ajuste constituiu-se de profundas transformações nas formas de produção da vida humana em todas as suas dimensões, em razão da própria racionalidade da formação socioeconômica capitalista. A base produtiva alterou-se com o avanço científico, reestruturou-se a economia em sua microdimensão perante o seu próprio movimento e o movimento ocorrido com a mundialização do capital, que transformou radicalmente as relações entre as grandes corporações e seu paradigma organizacional e de gestão. No âmbito político, a esfera pública restringiu-se e desregulamentou-se, num primeiro momento, para em seguida novamente se regulamentar, e assim possibilitar a expansão da esfera privada, a partir da iniciativa do Estado e mediante reformas estruturais orientadas por teorias gerenciais próprias do mundo dos negócios, em vez de por teorias políticas vinculadas à cidadania, ainda que ancoradas na concepção liberal.

Nessa nova fase, a ciência, a tecnologia e a informação, das quais se servia o capital em fases anteriores, tornam-se suas forças produtivas centrais, desenvolvidas sob seu monopólio. O dinheiro converteu-se no principal móvel econômico, em razão do modo de reprodução ampliada do capital concretizado pelo sistema financeiro via mundialização do mercado. As corporações transnacionais, escudadas em organizações financeiras como o Fundo Monetário Internacional (FMI), o Banco Interamericano de Desenvolvimento (BID), o Banco Mundial etc., assumiram o centro de poder em nível planetário, em detrimento dos anseios da sociedade civil, que supostamente se expressariam no Estado nacional. Como decorrência e componen- tes estruturais dessa nova fase, adquirem dimensão cada vez mais ampla o desemprego, a desestatização/ privatização do Estado e a terceirização da economia, legitimados pelas concepções ultraliberais, provocando intenso processo de mercantilização de espaços sociais, especialmente os da saúde e da educação. Acentuou-se o caráter mercantil da dimensão estatal, no âmbito da sociedade política (Sguissardi \& Silva Jr., 2001).

Esse processo de mercantilização provocou densas mudanças no ethos das instituições educacionais, por meio de suas relações com a sociedade e das reformas educacionais assentadas no trabalho abstrato, nessa nova forma histórica do capitalismo mundial e brasileiro; ou melhor, tendo-o como eixo central de sua estruturação e organização. Nesse momento as relações entre capital e trabalho conformam um campo novo na esfera trabalho/educação: o das pedagogias cognitivas e da polissêmica noção de competência. A um só tempo, a educação assume a centralidade nos discursos de gestores políticos e empresariais e de educadores, tendo a mídia em geral, com raras exceções, a lhes fazer entusiástico coro.

Seduzidos por tal centralidade, os trabalhadores cada vez mais assumem individualmente a busca de condições para se tornarem capazes e empregáveis por meio da educação escolar. Suas qualidades subjetivas parecem-lhes verdadeira mercadoria, algo objetivo, adquirido mediante pagamento e que os tornaria empregáveis numa sociedade cada vez mais sem emprego. Na esfera da educação superior, inicia-se uma nova fase de expansão e diversificação em todos os seus níveis e modalidades. Os Master Business Administration (MBA) tornam-se objeto de desejo de grande número de graduados das ciências sociais aplicadas (área que reúne quase 50\% das matrículas de graduação do país) e um grande símbolo dos novos tempos. A graduação desvaloriza-se e flexibiliza-se. Enfim, acentua-se a nova identidade da educação superior com novos traços: neoprofissional, pragmática, competitiva, submissa como jamais foi aos desígnios da economia e do mercado. Isso implica dizer que, na educação superior, surge um promissor mer- 
cado: a nova pós-graduação lato sensu e, no stricto sensu, o mestrado profissional, com pesadas consequiências para o novo desenho do Sistema Federal de Educação Superior, objeto, entre outros, do anteprojeto de lei em estudo.

Como se pode observar, a partir da segunda metade dos anos de 1990 vários traços culturais que fundam as relações sociais brasileiras repõem-se com nova forma histórica. $\mathrm{O}$ viés tecnicista da educação brasileira, complementada por supostos pragmáticos, como meio para consecução do desenvolvimento, repõe-se num pacto social, como vimos anteriormente, apoiado por Grajew (2002) e criticado por Vogt (2003), e expresso na Carta ao povo brasileiro. Em vez de uma ditadura, para a concretização do crescimento da economia nacional e conseqüiente bem-estar dos cidadãos, tem-se uma a democracia cujas instituições estatais intervêm em favor do capital industrial nacional, articulado ao capital financeiro, com o mesmo objetivo que o daqueles anos que não podem ser esquecidos.

Também se dão rupturas, como se pôde ler nessa sintética recuperação de continuidades e descontinuidades em nossa história recente. Ilustram-nas a descontinuidade dos movimentos sociais que reivindicavam políticas públicas para o atendimento ao déficit social e produtivo da década de 1980, e o fato de que, hoje, muitos deles, metamorfoseados em ONGs, passam a reivindicar verbas públicas ou não, nacionais ou não, para a realização do que outrora fora considerado direito social subjetivo do cidadão. A qualificação e a formação profissionais são um exemplo acabado dessa ruptura. A Central Única dos Trabalhadores (CUT), por exemplo, faz uso de forma intensiva das verbas do Fundo de Amparo ao Trabalhador (FAT) para esse fim, da mesma forma que o fazem muitas ONGs.

$\mathrm{Na}$ esfera superestrutural, as políticas públicas para o social, com destaque para a educação superior, outrora demanda da sociedade civil, tornaram-se políticas de oferta assentadas num orçamento orientado, de um lado, pelas agências multilaterais e por um Congresso Nacional fisiológico, e, de outro, pela demanda do capital nacional, com destaque para o in- dustrial, fato tornado possível pela reforma do Estado que acentuou a dimensão mercantil da educação e pelos fatores anteriormente delineados.

\section{O público, o privado, o estatal e o estatal/mercantil}

A forma atual do capitalismo no Brasil produziu uma regulação social que busca a "nova institucionalidade", assentada na busca do consenso entre antagonias por meio de política de negociação, submetida à política econômica aceita desde o início dos anos de 1990. Estruturou-se, institucionalmente, no mandato de FHC, e tende a realizar-se e a adensar-se decisivamente no atual mandato presidencial, do que poderá ser expressão, ainda que parcial, o anteprojeto de lei de educação superior ora em debate.

Diante do que se procurou mostrar no plano histórico, torna-se fundamental refletir sobre as relações entre as esferas pública e privada, e, sobretudo, sobre a dimensão estatal/mercantil e a nova identidade da instituição universitária presente no referido anteprojeto. Nesse sentido, deve-se partir do princípio de que a liberdade e a igualdade são uma utopia iluminista e de que a propriedade privada e suas conseqüências são uma dura realidade no contexto da inserção do Brasil na imperial universalização do capitalismo.

A discussão sobre a cultura que embasa as relações sociais hoje e que lhes confere a racionalidade histórica do momento atual deve considerar, necessariamente, pelo menos três amplos campos: a normatização institucional derivada do ordenamento jurídico do Estado moderno, sua organização específica que se origina nesse ordenamento, e a história específica das instituições da sociedade civil. Trata-se da natureza das instituições que, como o próprio substantivo indica, contribui para a instituição da cultura, e que realiza, em parte, o pacto social em determinado período histórico, produzindo em sua formação o lugar privilegiado do ethos público no âmbito da sociedade civil.

Segundo Locke (1991, p. 217), no estado natural da humanidade todos nascem iguais, racionais $\mathrm{e}$ 
em liberdade; as leis da natureza se encontrariam igualmente nas mãos dos indivíduos, não existindo ainda o espaço societal. Os homens estabeleceriam sua identidade por meio da razão, com vista na preservação da paz e dos direitos naturais de todos, com o objetivo de continuidade do gênero humano. Um desses direitos pensados por Locke, ainda que não inato, é a propriedade, pois deriva do trabalho, por ele considerado extensão do próprio corpo humano. No entanto, no estado natural, os direitos de igualdade, liberdade e propriedade - dada a complexificação dos modos de vida dos seres humanos produzidos por meio do trabalho simples e de seus resultados - podem ser ameaçados, porque alguns homens, favorecendo mais a si e a seus amigos, acabariam por provocar um claro estado de guerra. Isso contraria o estado natural, bem como os direitos próprios desse estado. Locke deduziria então a necessidade de superação, pelo homem, desse estado natural. Para ele, "é razão decisiva que os homens se reúnam em sociedade deixando o estado de natureza", visando ao estabelecimento de um poder político terreno que emergisse da sociedade e a ela se submetesse a fim de eliminar-se "a continuidade do estado de guerra” (Locke, 1991, p. 224). Disso se poderia depreender que esse movimento, resultante no poder político e no Estado, tem como fim último a continuidade do gênero humano ou o desenvolvimento histórico da qualidade que haverá de identificá-lo: a humanidade.

Os homens teriam feito então um pacto social e criado a sociedade política para a preservação dos direitos naturais, ou seja: o pacto social fora feito no estado natural com o objetivo de garantir os direitos de igualdade, liberdade e propriedade de qualquer indivíduo em sociedade, independentemente de suas condições naturais, disso derivando a continuidade e a complexificação do gênero humano. Em acréscimo, não haveria renúncia dos direitos naturais em favor dos governantes, como o queria, por exemplo, Hobbes; há um pacto para a preservação dos direitos de todo cidadão na sociedade - a constituição do ethos público. O poder dos governantes do Estado e de suas instituições, portanto, derivaria da sociedade, por outorga desta, e do que decorreria, portanto, a submissão do poder político e do Estado moderno ao povo, ao público, isto é, à sociedade, sempre tendo como objetivo reiterar e intensificar a continuidade do gênero humano. Nesse momento, o institucional, com o traço histórico desse tempo, fora produzido pelos e para os seres humanos e concretizado pelo pacto social.

No Estado moderno está toda a origem histórica do institucional e do político de qualquer instituição ou organização da sociedade atual. A existência humana e suas necessidades decorrentes em sociedade precederam a produção histórica do Estado moderno e de suas instituições para a construção, regulação e consolidação do pacto social (Locke, 1991, p. 225). Convém aqui destacar desde logo que o público identifica-se com a sociedade, de um lado, dando origem ao poder político que se materializará no Estado, e, de outro, que o público se torna o pólo antitético do privado no âmbito da sociedade e do Estado. Disso se pode concluir, ainda com Locke, que a natureza institucional do Estado moderno e do poder político por ele exercido emerge da sociedade e a ela deve submeter-se. Por essa razão, desde a criação do Estado, e particularmente do Estado moderno, existe uma contradição entre o público e o privado em qualquer esfera de atividade humana, especialmente no interior do próprio Estado e de suas instituições, por ação dos atores que neles trabalham. Tal contradição histórica deriva, de um lado, da outorga das atividades de legislar, julgar e executar, que são individuais no estado natural, para a esfera normativa do pacto social (o Estado), e de outro lado, da instituição mesma que sustenta o pacto social por meio do poder político, que é o próprio Estado. Assim, pode-se apontar para um duplo movimento que produziria a indissociável contradição público/privado na sociedade e no Estado moderno. Isso implica afirmar a predominância de um pólo da contradição, o público, ou do seu antitético, o privado, em função de como se organizam a sociedade, o Estado e as relações entre eles mediadas pelo poder político, com base na natureza e na economia. No entanto, como seu lugar é a socie- 
dade, seu ethos deve ser, segundo a concepção liberal clássica, predominantemente público. Nesse quadro configura-se o pacto social e seu produtor, o cidadão, bem como a qualidade de ser cidadão: a cidadania. Em acréscimo, como ele deve pensar, agir e organizar-se para realizar a função precípua do Estado moderno, do institucional, do poder político e da cultura que sedimentam e consolidam o pacto social na modernidade. ${ }^{6}$ Estabelece-se, assim, nesse modo de produção da vida humana, com muitas formas históricas diferentes, uma contradição que permeará todas as atividades dos indivíduos no campo da sociedade e do Estado, realizadas no terreno da política, destacando-se nesse momento a contradição entre o público e o privado. Na modernidade, portanto, não cabe pensar no fim do público ou do privado, mas organizar a sociedade para que a contradição entre esse pólos seja sempre superada por meio da política em direção àquele, o público, "em prol do bem público" (Locke, 1991, p. 223), isto é, da sociedade, para a realização de seus objetivos de origem, dentre eles a intensificação da qualidade de existência e a continuidade do gênero humano.

Assim, posto que o público se identifica com a sociedade, com a organização do Estado e com o poder político exercido pelos governantes, cabe à sociedade, na perspectiva liberal, ainda segundo Locke, cuidar para que o poder político a ela se submeta, e que o pólo público da contradição seja sempre o mais forte em razão de suas características de origem histórica. Se o contrário ocorrer, será por vontade política da sociedade, que pode não estar esclarecida da constituição histórica de sua vida cotidiana em sociedade. Pode estar embasando seu modus vivendi numa

\footnotetext{
${ }^{6} \mathrm{Na}$ radicalidade dessa filosofia política, no fim do mercantilismo e no início da construção das bases econômicas do capitalismo, a política controlaria a economia e a propriedade privada. Nesse momento não há densidade histórica para argumentar-se sobre a contradição entre igualdade e liberdade e a propriedade privada, suposto que, quase cem anos depois, Rousseau tomaria para explicar a desigualdade social entre os homens.
}

visão de mundo que mais oculta do que revela o Estado como uma instituição autônoma sem sua âncora na própria sociedade, na economia e na natureza.

Por sua vez, Adam Smith, analisando o capitalismo quase um século mais tarde, mostra em A riqueza das nações (1993) que o Estado capitalista, para além de representar o capital mediante uma autonomia política relativa, sempre teve um papel econômico, sem o qual o capital jamais se reproduziria plenamente de forma privada, isto é, pela "mão invisível do mercado".

Adam Smith mostra o papel político, mas também o econômico e o belicoso do Estado moderno, antevendo o século da socialdemocracia e dos presentes diagnóstico e soluções neoliberais, ao mesmo tempo em que oferece a chave para desvendar o período do liberalismo clássico, isto é, a contradição entre a igualdade, a liberdade e a propriedade privada. Segundo Smith, a primeira das despesas do Estado moderno é com a defesa, em seguida, com a justiça, para a garantia da propriedade privada, o que resulta na desigualdade social entre os homens e no aflorar dessa contradição. Isto é, sua teoria econômica somente se sustenta se existir um Estado com tais funções. Diante da inevitável desigualdade social dessa condição, afirma a necessidade inarredável do ordenamento jurídico burguês.

O terceiro aspecto a que Smith faz referência é a despesa do Estado com serviços ou mesmo instituições que possam interessar a uma ou várias unidades de capital: "a criação e a manutenção dos serviços públicos que facilitam o comércio de qualquer país, [...] boas estradas, pontes, canais navegáveis etc. exigirão variadíssimos níveis de despesas nos diferentes períodos da sociedade" (Smith, 1993, p. 335). A educação é também, para ele, parte de tais despesas: um serviço público. Smith desvela no campo da economia o fetiche do Estado liberal e torna clara a contradição entre o público e o privado, presente nas relações econômicas e sociais. Trata-se de um Estado que, em sua origem, submete a dimensão pública à esfera privada, em benefício desta última. Mostra assim a tendência histórica de intensificação da dimensão es- 
tatal/mercantil que faz com que o Estado dirija suas políticas públicas para o pólo privado da contradição, dada a materialidade da economia. Lendo-se $A$ rique$z a$ das nações tendo em vista o momento atual, vê-se que existe uma linha de continuidade: as mudanças na forma de Estado estão tendencialmente sempre a serviço do capital. As modificações das esferas pública e privada, como se pode observar, mantêm relação entre si, influenciadas, com mediações, pela realização do valor na esfera da circulação de mercadorias. O valor produzido no âmbito da produção é potência, podendo realizar-se ou não na esfera da circulação de mercadorias, o que teria levado Marx (Marx \& Engels, s.d., p. 24) a dizer que a burguesia necessita revolucionar-se sempre para se manter. Há, portanto, uma diferença de timing entre a produção e a realização do valor. Além disso, a demanda do capital é diferente da demanda da classe trabalhadora. $\mathrm{O}$ foco daquele são os meios de produção; o desta são os produtos necessários para sua própria reprodução, mediante seu trabalho alienado. Isso, segundo Marx, provocaria crises cíclicas de superprodução de capital nas suas diversas formas (matéria-prima, força de trabalho, produto acabado, capital financeiro etc.). Isso significa, no médio prazo, queda da produção, dívida interna, inflação e desemprego, além de alta tributação. As teses da socialdemocracia e do Estado de bem-estar social terminaram, dessa forma, na década de 1970, sendo substituídas pelas propostas neoliberais. Logo o mundo passaria por reformas do Estado, das instituições que dele derivam, e a busca de novo pacto social pragmático e de nova forma histórica do capitalismo reatualizaria a contradição público/privado por meio das cruzadas reformistas. $\mathrm{E}$ a dimensão central estatal/mercantil acentuou-se ainda mais. Fez-se necessário ancorar o montante de capital da esfera financeira na materialidade do capital produtor de valor e de mercadorias.

Em contrapartida, a dimensão estatal/mercantil tem escamoteado a contraposição estatal/público versus privado/mercantil. Para Emir Sader (2003), a esperteza da estratégia neoliberal consistiu em acentuar a suposta contraposição estatal/privado, em lu- gar da oposição real público/privado e, nesse caso, especialmente o pólo privado/mercantil. Esse deslocamento seria extremamente favorável à estratégia neoliberal. Para que essa estratégia tenha êxito, demoniza-se o estatal como sendo o exclusivo reino da ineficiência, da burocracia, da corrupção, da opressão, da extorsão (de impostos) e da má prestação de serviços, e sacraliza-se o privado como sendo o reino exclusivo da liberdade, da criatividade, da imaginação e do dinamismo. Com essa contraposição, aparentemente correta, tira-se de cena um termo essencial, isto é, o público. A grande arma da estratégia neoliberal, segundo Sade, foi transformar um campo de disputa hegemônica, hoje "hegemonizado pelos interesses privados" (o estatal), num simples pólo de contraposição com o privado, que, por sua vez, não se constitui em exclusiva esfera dos indivíduos, mas também dos interesses mercantis, como tantas operações de privatização muito recentes, chamadas de desestatização, teriam demonstrado. A "universalização dos direitos", conclui Sader, compõe a verdadeira essência do público, enquanto a "mercantilização do acesso ao que deveriam ser direitos: educação, saúde, habitação, saneamento básico, lazer, cultura" (Sader, 2003, p. 3), corresponde à essência do mercado ou do privado/mercantil.

As políticas públicas passam, no Brasil e no exterior, por um processo de mercantilização ancorado na privatização/mercantilização do espaço público e sob o impacto de teorias gerenciais próprias das empresas capitalistas imersas na suposta autonomia ou real heteronomia do mercado, hoje coordenado por organismos multilaterais a agirem em toda a extensão do planeta. Quando titular do Ministério da Reforma do Estado e da Administração Federal (MARE), Bresser Pereira assim argumentava sobre a necessidade de uma "nova administração pública":

A abordagem gerencial, também conhecida como "nova administração pública", parte do reconhecimento de que os Estados democráticos contemporâneos não são simples instrumentos para garantir a propriedade e os contratos, mas formulam e implementam políticas públicas estra- 
tégicas para suas respectivas sociedades, tanto na área social quanto na área científica e tecnológica. E para isso é necessário que o Estado utilize práticas gerenciais modernas, sem perder de vista sua função eminentemente pública (Bresser Pereira, 1996, p. 7).

Depois de analisar os condicionantes históricos dos paradigmas de administração pública já existentes - o patrimonialista e o burocrático - e de criticálos, Bresser Pereira assim se manifesta sobre o que propõe para a administração do aparelho de Estado em construção:

Como a administração pública burocrática vinha combater o patrimonialismo e foi implantada no século XIX, no momento em que a democracia dava seus primeiros passos, era natural que desconfiasse de tudo e de todos - dos políticos, dos funcionários, dos cidadãos. Já a administração gerencial, sem ser ingênua, parte do pressuposto de que já chegamos a um nível cultural e político em que o patrimonialismo está condenado, que o burocratismo está condenado, e que é possível desenvolver estratégias administrativas baseadas na delegação de autoridade e na cobrança a posteriori de resultados. (idem, p. 272)

O propósito do ex-ministro Bresser Pereira torna-se explícito nessa lógica da reforma do Estado, tanto no que se refere às instituições já citadas quanto em relação à esfera pública: trata-se de introduzir, no domínio social, mediante a construção de um pacto social pragmático, a racionalidade gerencial capitalista e privada, que se traduz na redução da esfera pública ou na expansão da privada, mas, sobretudo, na acentuação da dimensão estatal/mercantil (e privado/ mercantil) com sua racionalidade organizativa.

É com base nessa breve análise da realidade, que contextualiza as políticas públicas recentes, especialmente de educação superior, e na reflexão exigida pela materialidade histórica que envolve tanto a contradição público/privado quanto a dimensão central e mercantil do Estado moderno, que se pode compreender melhor a racionalidade político-administrativa do governo FHC e dos dois primeiros anos do governo Lula.
Pode-se entender também os possíveis e prováveis vínculos do anteprojeto em pauta com a reforma gerencial do Estado do ex-ministro Bresser Pereira, e com todas as demais reformas pontuais que ao longo dos últimos anos vieram se efetivando no campo do aparelho do Estado e das políticas públicas.

Enfatize-se que no processo de reprodução social, além de se reproduzirem as relações de produção do capital, reproduzem-se também as contradições de sua produção, podendo o Estado tender ao máximo para o pólo privado da contradição público/ privado nele presente e apresentar-se como gestor autoritário e centralizador, em cuja cultura predominem os valores mercantis, nos limites de um dado período histórico. Por exemplo, quando ocupado por um governo que, apresentando-se como popular e democrático, tende a implementar políticas e medidas de reforma que fortalecem contraditoriamente a mercantilização do bem público, sem que este último jamais deixe de existir, ao menos na modernidade.

Da sucinta análise histórico-filosófica anterior pretende-se derivar a categoria de identidade da educação superior na modernidade e seus princípios constitutivos básicos, para, em seguida, utilizá-los - categoria e princípios - como critérios ou parâmetros da análise do anteprojeto de lei de educação superior de 6 de dezembro de 2004.

\section{Identidade histórica da universidade}

Nos tempos modernos, a instituição universitária possui em geral identidade e perenidade histórica próprias, das quais se originam seus princípios para além do plano lógico, diversamente do que pretenderiam muitos reformadores. A universidade atual - originária do Estado moderno e cujos objetivos sociais e forma organizacional são destinados à manutenção $\mathrm{e}$ regulação do pacto social contemporâneo - deve concomitantemente contribuir para a construção da consciência crítica institucional deste tempo histórico da humanidade. Assim, toda a política relativa à universidade haverá de ser uma política de Estado, e não de governo, tendo por objetivo ordenar as relações que 
materializam a sociedade na direção da intensificação de seus traços de humanidade.

\section{Princípios}

\section{Da relação público/privado}

Posto que, na modernidade, a contradição público/privado é intrínseca a toda esfera da atividade humana, a universidade deve organizar-se e manter sua dinâmica interna e suas relações com a sociedade e com o Estado voltadas para o pólo público, restringindo ao máximo o espaço do pólo antitético, o privado. Disso decorrem ao menos dois corolários:

a) As políticas para a educação superior serão sempre políticas públicas de Estado, não orientadas por objetivos focais ou que se ponham como formas de privatização política e econômica como as que hoje ocorrem, ainda que aparentemente discutidas de modo aberto com a sociedade civil, como, por exemplo, é o caso do PROUNI - forma de aplicação, lato sensu, no campo da educação, da parceria público/ privado - ou o da inovação tecnológica - forma de implemento de traços de efetiva heteronomia diante da frágil autonomia universitária das instituições federais de educação superior, da sua imprópria carreira docente e respectiva (e incongruente) remuneração salarial. Esses traços contribuiriam para criar as bases da neoprofissionalização da universidade e de seu respectivo empresariamento, em nítida colisão com o teor deste corolário, derivado do princípio da relação público/privado, pilar inconteste da doutrina liberal clássica do Estado.

b) As instituições universitárias privadas devem apresentar-se como uma alternativa para a sociedade civil somente quando o Estado não tenha condições de responder sozinho às demandas públicas de educação superior. Essas instituições, autofinanciáveis, não devem existir senão em conformidade com os ditames constitucionais da identidade universitária, da qualidade requerida de um bem público, sem ônus para o erário, direto ou indireto, na forma de isenção de impostos ou de parcerias com o Estado, como se quis, no governo anterior, com as pretendidas organizações sociais do ex-ministro Bresser Pereira e quando, a qualquer custo, são aprovadas, pelo Congresso Nacional, leis como as acima citadas, no governo atual.

\section{Da autonomia universitária}

O princípio da autonomia congrega os elementos fundantes da identidade universitária, ainda que coexistindo com a contradição público/privado presente no primeiro princípio. Por hipótese, a universidade deveria gozar de autonomia, para além do ordenamento jurídico estabelecido pelo Estado moderno, com o fim de concretizar suas razões de ser: contribuir para a manutenção e regulação do pacto social contemporâneo, fundado na economia, e para a consciência crítica institucional desse tempo histórico da humanidade.

Esse princípio tem sua contraposição, hoje cada vez mais real, na heteronomia, que, no dizer de Daniel Schugurensky (2002, p. 109), é aquela situação em que "setores externos (principalmente o Estado e a indústria) têm cada vez mais poder na definição da missão, da agenda e dos produtos da universidade". Autonomia sugere autodeterminação, independência e liberdade; heteronomia, subordinação a ordens e agentes externos, adequação a demandas mercadológicas, a agendas estatais marcadas pelo pólo privado/ mercantil.

Disso decorrem alguns corolários:

a) O princípio da autonomia insere uma contradição, tributária de cada época: ao mesmo tempo em que deve ser uma instituição crítica de seu tempo, o faz para a preservação da racionalidade social nele instituída. Isso implica dizer que sua organização e sua gestão devem pender sempre para o público, seja no campo universitário em geral, seja numa instituição em particular. 
b) Por essa razão, não cabem em absoluto restrições à autonomia científica (no campo da liberdade acadêmica) das universidades, como as postas hoje pelos sistemas de avaliação (graduação, que se guiam pelas diretrizes curriculares, e pós-graduação, que se guiam por diretrizes estreitas de ciências aplicadas), pela Lei de Inovação Tecnológica e pelos fundos setoriais, que tendem a induzir a pesquisa universitária na direção do mercado. A autonomia científica vê-se a cada dia mais tutelada pelos interesses privados do Estado e do mercado.

c) A instituição universitária pública e estatal terá garantida sua autonomia, segundo sua identidade, se e quando for integralmente mantida pelo Estado, entendido nos termos da doutrina liberal clássica e nos termos constitucionais (Constituição Federal de 1988, art. 207). Disso decorre o sem sentido de manipulações semânticas como as que pretenderam igualar os termos constitucionais da autonomia de gestão financeira com os da autonomia financeira.

Do financiamento da universidade

O princípio do financiamento é tributário de todos os anteriores. Se o financiamento tiver sua origem em políticas públicas de oferta formuladas de acordo com um orçamento produzido segundo uma racionalidade diferente da que deu origem ao poder político e ao Estado, isto é, que privilegiem o ethos privado - situação sempre possível diante da existência, em toda esfera de atividade humana, da contradição público/privado -, a identidade da instituição universitária estará comprometida na sua capacidade de crítica institucional de seu tempo histórico. Ter-se-ia então como corolários:

a) A ausência dos princípios da autonomia e da democracia universitárias e da relação universidade/sociedade.

b) A necessidade de reiterar a ênfase no ethos público como base do financiamento como ga- rantia da origem e submissão do poder político e do Estado à sociedade civil.

c) O financiamento da educação superior como um investimento político público e social a contribuir para a soberania da nação e preservação de sua unidade cultural.

d) A educação superior como um bem político público, jamais um bem econômico de caráter privado, como pretendeu e pretende a Organização Mundial do Comércio (OMC), no âmbito do Acordo Geral sobre o Comércio de Serviços (AGCS). ${ }^{7}$

Disso decorre que é na categoria de identidade da universidade moderna que se funda o fato de que o financiamento da educação superior pública deve ser estatal e refletir as reivindicações da sociedade civil, o que fortalece o ethos público na sociedade - e na universidade - conforme o sentido histórico e legítimo da origem do poder público e do Estado.

Da democracia universitária e da relação universidade-sociedade

O princípio da democracia universitária decorre da contradição em que se constitui o princípio da autonomia. A universidade, ainda que tenha que se submeter ao ordenamento jurídico do Estado, de alguma forma reciprocamente o submete, posto que aquele deve submissão à sociedade, isto é, ao ethos público. É, portanto, também em um espaço de contradição que se move a democracia universitária.

Disto decorrem os seguintes corolários:

a) Se o Estado se fizer autoritário, numa dada sociedade, a democracia universitária tenderá a não ter a força do pólo social público e a ceder ao ordenamento jurídico centralizador. Se isso ocorrer, não haverá democracia real, mas democracia tutelada pela burocracia estatal. Não

\footnotetext{
7 Sobre o assunto, ver Siqueira (2004).
} 
se terá autonomia, mas heteronomia. A presença de regras e exigências centralizadoras, como as aparentemente relacionadas ao Plano de Desenvolvimento Institucional (PDI), que seriam reforçadas pela nova legislação, coloca problemas para o estatuto da autonomia: as instituições teriam que se adaptar a princípios reguladores definidos de forma centralizada pelo Estado, que, como se pôde observar anteriormente, está, ao longo dos últimos governos, com seu pólo privado fortemente exacerbado. Novamente os papéis da sociedade e da comunidade universitária têm lugar relevante para a manutenção da identidade da instituição universitária pública e estatal, isto é, o ethos público deve orientar as ações de cidadania e práticas no interior da universidade.

b) Se, ao contrário, ocorrer um regime político de fato democrático, a sociedade civil será mantida em um paradigma de políticas públicas e estatais de demanda social, o que tenderá cada vez mais a fortalecer o ethos público. Nesse sentido, as práticas acadêmicas devem realizar-se conforme os parâmetros da identidade universitária, isto é, próximas das demandas sociais e da sociedade civil. Se as políticas são de demanda social, a cultura mercantil haverá de paulatinamente enfraquecer-se, deixando de macular a identidade histórica da universidade.

c) Na relação da universidade com a sociedade origem do ethos público - mediante a associação ensino, pesquisa e extensão, nenhuma dessas atividades-fim da universidade deve se prestar, por qualquer razão, à complementação de orçamentos universitários insuficientes, mormente quando estes resultam de políticas administrativo-financeiras deliberadas de governo que visam a forçar a dependência externa, isto é, a heteronomia. É inaceitável, ainda, que o Estado produza programas voltados exclusivamente para o pólo privado, isto é, que inibam a realização da potência da identidade universitária, historicamente produzida para a manutenção do gênero humano e intensificação de sua qualidade de existência: a humanidade. O exemplo dos fundos setoriais é oportuno: conduziriam à submissão da universidade ao campo da economia, por induzirem à produção científica vinculada a campos específicos e de um singular projeto político de governo, em vez de vinculada a um plano estratégico de longo prazo, numa verdadeira política de Estado. Mais inaceitável ainda é a produção de leis que estabeleçam vínculos institucionais universidade-empresa privada de tal natureza que conduzam à efetiva promiscuidade dos interesses públicos com os interesses privado/ mercantis (imediatistas, utilitários, pragmáticos, de domínio e de lucro), atentando contra a identidade universitária como bem público, a pretexto de alavancagem do desenvolvimento tecnológico nacional, como seria o caso da Lei de Inovação Tecnológica.

\section{Da avaliação universitária}

A avaliação é um momento ético da prática universitária, no qual os atores institucionais devem ponderar se estão consolidando, no que fazem, uma cultura que realize a identidade da instituição universitária. No entanto, também aqui se coloca o ordenamento jurídico, dada a origem estatal da universidade. Assim sendo, a avaliação universitária pode tornar-se um obstáculo a comprometer os demais princípios, bem como a própria identidade universitária. Aqui novamente é necessário indagar: qual dos pólos da contradição público/privado está sendo fortalecido pela avaliação universitária, diante de um determinado projeto acadêmico-científico da instituição universitária? Quais são as dimensões essenciais do processo de avaliação: a auto-avaliação, a autoformação, a responsabilidade perante suas funções ou finalidades históricas, ou sua regulação, seu controle, segundo os cânones da heteronomia? Se a avaliação fortalecer tão somente a dimensão mais instrumental e pragmática da identidade da instituição universitária, ela estará contribuindo para 
a destruição da instituição. Isso novamente coloca em destaque a natureza imprescindível da sociedade e da comunidade universitária para, em seu movimento, acentuar o pólo público da contradição, e jamais seu antitético. É nesses termos que se pode examinar a pertinência ou não do PDI nos termos em que está sendo posto.

\section{Da associação ensino, pesquisa e extensão}

As amarras históricas do conhecimento, de sua produção e socialização, que estão no centro da associação ensino, pesquisa e extensão, devem ser objeto de exame de todo cidadão, mas cabe a todos os atores universitários jamais permitir a submissão do conhecimento a uma determinada racionalidade social, pois nessa condição seriam negados a identidade universitária e todos os princípios dela decorrentes. O conhecimento é por si transgressor. Se não o for, não é conhecimento, é instrumento a serviço de projeto político de governo que entende o Estado de forma autônoma em relação à sociedade civil e à economia, o que pode levar - e legitimá-los - aos totalitarismos que vicejaram ao longo do século XX.

Um governo que não respeite tal identidade na instituição universitária, que não institua uma política de Estado para a educação superior, estará negando sua cultura (universitária) e sua própria identidade (universitária), mantida ainda que sob modos de produção muito diversos. Lutar contra essa densidade histórica, entretanto, seria o mesmo que imitar Dom Quixote: investir bravamente, mas sem sucesso nem glória, contra moinhos de vento.

\section{Por que uma nova lei de educação superior?}

Como consta da introdução deste artigo, uma lei não comporta toda a reforma. $\mathrm{O}$ anteprojeto em pauta, nas condições e circunstâncias em que é proposto, não poderia fazer tábula rasa da legislação anterior, mormente das normas legais aprovadas no atual mandato presidencial, que a nova lei tenderá a consolidar. Em escala variada, essa nova lei tenderá a ser uma continuidade das leis $\mathrm{n}^{\circ} 10.861$ (de 14/4/2004, que criou o SINAES, assim como da portaria MEC $\mathrm{n}^{\circ} 2.051$, de 9/7/2004, que o instrumentou), $\mathrm{n}^{\circ} 10.973$ (de 2/12/2004, relativa à inovação tecnológica), $\mathrm{n}^{\circ}$ 11.079 (de 30/12/2004, sobre as parcerias público/ privado), no 11.096 (de 13/1/2005, do PROUNI). Além disso, ela é proposta na vigência de normas legais que regulamentam os fundos setoriais e as diretrizes curriculares para a graduação, entre outras.

Apesar da existência, na Lei de Diretrizes e Bases da Educação Nacional (lei no 9.394/96), de um capítulo que regulamenta a educação superior, e de um arsenal de medidas legais promulgadas em governos anteriores e no atual, poucos poderão negar a urgência de uma lei dessa natureza. As razões para tanto são muitas, constem ou não da justificativa oficial do atual anteprojeto:

a) a perda de identidade histórica da educação superior, poucas instituições merecendo hoje o nome de universidade ou instituição de educação superior;

b) a indiferenciação entre o interesse público e privado especialmente, nesse caso, o privado/ mercantil;

c) a importância estratégica da educação superior para o desenvolvimento e o plano inferior a que em geral tem sido relegada no Brasil desde os governos militar-autoritários, quando se iniciou de fato a pós-graduação;

d) a baixíssima cobertura, mesmo se comparada à de países da periferia e semiperiferia mundiais, que não chega a $15 \%$ em termos absolutos e a $10 \%$ da faixa etária de 18 a 24 anos;

e) a desigual expansão entre os setores público e privado, que conduziu a uma tal repartição do alunado de graduação em que o setor privado já detém cerca de $3 / 4$ do total de matrículas e avança célere para $4 / 5$;

f) a restrição da expansão do setor público federal nos últimos dez anos, com gradativas e constantes reduções orçamentárias $(0,91 \%$ do PIB em 1994 para 0,51\% em 2004), com degrada- 
ção da infra-estrutura e das condições de trabalho (incluindo carreira e salários), e redução dos corpos docente e técnico-administrativo, além da ausência de autonomia administrativa e de gestão financeira, ao arrepio da Constituição;

g) a falta de efetiva regulação e controle das prestadoras privadas desse serviço público essencial, o que tem contribuído para sua expansão desenfreada, sem a esperada e necessária qualidade, e para a mercantilização progressiva do saber universitário;

h) a ausência da pesquisa e a baixa qualidade do ensino, especialmente nas quase duas mil instituições privadas de ensino superior do país.

Por razões analíticas, diante do já exposto e para melhor exame do anteprojeto, pergunta-se: a que deveria visar uma lei de educação superior? Pode-se responder que a lei deveria visar:

a) à restauração da identidade histórica da instituição universitária, ainda que nos moldes do liberalismo clássico moderno, recuperando-se o ethos acadêmico que define o fazer universitário, isto é, produção de conhecimento como bem público, liberdade de pensamento, crítica social, formação de pesquisadores e de profissionais qualificados;

b) à garantia do estatuto da autonomia, em suas diferentes formas, e não submissão aos interesses do Estado e do mercado;

c) ao fortalecimento do pólo público e o combate à mercantilização;

d) à garantia do financiamento público suficiente para as necessidades atuais e de expansão das instituições públicas, com gratuidade, nos termos constitucionais;

e) à garantia da qualidade da pesquisa, do ensino e da extensão, mediante planejamento, condições materiais, físicas e humanas, e avaliação;

f) à democratização crescente da educação superior, seja do ponto de vista do acesso cada vez mais amplo da população, seja do ponto de vista da gestão organizacional, respeitado o mérito acadêmico e a autonomia.

Dadas as reações multipolarizadas que o anteprojeto tem provocado em interlocutores de diferentes posições no campo da educação superior - setor público federal e estadual, setor privado comunitário-confessional ou privado-comercial, entidades científicas ou de classe etc. -, vale a pena pontuar: primeiro, que o saber é um bem público, que a universidade atual nasce com o Estado moderno para a manutenção e regulação do pacto social contemporâneo, que "o ensino, não se o pode tomar como objeto de mercancia", e que "o Estado é responsável pela sua prestação à sociedade" (Grau, 2005, p. 3); segundo, que, mesmo prestados pelo setor privado, os serviços educacionais são serviços públicos, e que, ao mesmo tempo em que a Constituição Federal de 1988, em seu artigo 209, diz que eles podem ser oferecidos pela iniciativa privada, impõe a exigência "do cumprimento das normas gerais da educação nacional, e autorização e avaliação de qualidade pelo poder público" (idem, ibidem).

Verifica-se na proposição dos mentores ministeriais, além da intenção de fortalecimento do setor público, uma efetiva e necessária regulação do setor privado, mormente o com fins lucrativos ou comerciais, hoje gozando de reduzidos controles, que the permite desenfreada expansão e insuficiente qualidade. A valorização do setor público será discutida mais adiante. Cabe aqui algum comentário breve sobre o combate, pela via da lei, ao descontrole/desregulação vigente, especialmente do setor privado/mercantil.

Além do risco de, eventualmente, minuciosa regulamentação poder vir a sufocar a liberdade de ensino e pesquisa, o que é, na perspectiva de uma política de Estado, uma preocupação bastante pertinente, existe o risco não menor de uma regulação tecnicamente mal concebida e mal elaborada. Do ponto de vista da técnica legislativa e do respeito às normas constitucionais, é vital não haver falhas. Do contrário, se barrada a forma da regulação proposta, quando da tramitação parlamentar do anteprojeto ou em pleitos judiciais posteriores, isso poderia significar um lamentável retro- 
cesso em relação à situação atual, já de si inaceitável. A boa intenção não basta: é preciso traduzi-la em termos juridicamente viáveis e em mecanismos de controle e regulação eficazes. O essencial é que se legisle de modo a garantir a identidade universitária perdida, sinônimo de autonomia e liberdade de ensino, e, ao mesmo tempo, de qualidade de pesquisa, ensino e extensão associados, tanto nas instituições de educação superior públicas quanto nas privadas, sejam elas organizadas como universidades ou como centros universitários ou faculdades isoladas.

\section{Conclusão}

A análise do anteprojeto de lei de educação superior, composto de cem artigos na versão de 6 de dezembro de 2004, pode ser feita de diferentes formas. Poderia ater-se à contextualização histórica de sua elaboração e a algumas de suas questões essenciais ou, além disso, abordar também aspectos pontuais ou secundários que interessam a muitos e diferentes interlocutores. No caso destas reflexões, após o que foi exposto sobre o contexto político-econômico e a definição de categorias e princípios necessários para a análise de qualquer documento dessa natureza, será observado, em linhas gerais, fazendo-se breves comentários críticos, como nele se revelam a relação público/privado, o estatuto da autonomia, o financiamento, a democratização, a relação universidade/sociedade/mercado, a avaliação e a associação ensino, pesquisa e extensão (princípio central e instituidor do trabalho acadêmico dos professores nas instituições de ensino superior); numa palavra, como se traduzem as exigências e condições para a recuperação da identidade universitária no contexto político-econômico.

Com base no exposto, indagamos: é possível afirmar que o anteprojeto, se transformado em lei na forma presente, irá contribuir de modo substancial para:

a) o fortalecimento do setor público da educação superior e do pólo público da universidade, e que estará estabelecendo efetivos marcos regulatórios para o setor privado, especialmente o privado/mercantil?

b) um efetivo exercício da autonomia pelas instituições de educação superior públicas e privadas?

c) a criação de padrões de financiamento das instituições de educação superior federais que lhes permitam não apenas a recuperação de índices históricos de recursos em relação ao PIB e condições estruturais tidas como muito melhores em tempos idos, mas a sua expansão, com qualidade, para que se cumpram as metas do Plano Nacional de Educação e para que possam funcionar no pleno exercício de sua (finalmente, agora proposta) autonomia administrativa e de gestão financeira e patrimonial?

d) a transformação das práticas universitárias democratização, avaliação e trabalho acadêmico - em meios de concretização do pólo estatal público da universidade?

Apesar da sua extensão e da pertinência específica de grande número de capítulos e artigos que definem a abrangência da lei, a função social da educação superior e os objetivos a que ela deve atender, das normas para garantia de uma melhor regulação do setor privado stricto sensu, assim como da proposta do estatuto da autonomia, em seus diferentes aspectos constitucionais, e da subvinculação orçamentária para supostamente garantir, por meios jurídicos e sem menção a suas bases econômicas, a manutenção financeira das instituições federais de educação superior, o anteprojeto apresenta uma série de limitações em sua formulação, que impedem uma resposta substancialmente positiva às questões acima expostas. Limitações que serão apenas parcialmente abordadas nesta análise preliminar.

Para que se dê o fortalecimento do setor público na educação superior e, nela, de seu pólo público, a lei deve estabelecer e definir normas para políticas públicas de Estado. Entre outras coisas, é necessário que: 
a) faça nítida distinção entre o interesse público e o interesse privado; que explicite o caráter estratégico da educação superior universitária, fato que se traduzirá pelo lugar que esta deverá ocupar nas prioridades orçamentárias da União e pela produção científico-tecnológica e cultural capaz de, no campo econômico e social, contribuir para efetiva independência e soberania do país; e

b) deixe claro que a educação superior é um serviço público de responsabilidade do Estado, um bem público, e não mercantil (direito social e subjetivo do cidadão, nos termos da doutrina liberal), e que apenas subsidiariamente cabe à iniciativa privada oferecê-lo a suas expensas, desde que estritamente obedecidas as normas gerais da educação nacional, com autorização e avaliação pelo poder público.

Em contrapartida, parece esdrúxulo, por exemplo, definirem-se, na lei, metas quantitativas a serem alcançadas em determinado prazo, o que caberia a planos nacionais de educação ou a programas de governo, não a uma lei que deve reger a definição, expansão e democratização em grau máximo desse serviço público. O mesmo se pode dizer do que consta no anteprojeto acerca da assistência estudantil e, eventualmente, da questão das políticas de ações afirmativas e contribuições sociais da educação superior.

Analisado pelo ângulo que até aqui se enfatizou, o anteprojeto mostra-se o embrião de uma lei única de reforma da educação superior brasileira, quando esta é um processo contínuo e contraditório que se inicia com o movimento da reforma do Estado no octênio anterior e orienta-se até o momento, no atual governo, pela mesma matriz política, teórica e ideológica (Sguissardi \& Silva Jr., 2001).

Aquelas orientações puseram o país a reboque da recente universalização capitalista, com forte crença, aparentemente modernizadora, de sua inexorabilidade. Foi nesse contexto que se realizaram as reformas do Estado e da educação superior. Assim, as instituições federais de ensino superior se profissionalizaram conforme as orientações gerenciais e pragmáticas com origem no Estado. Ao mesmo tempo, também se profissionalizaram a ciência e seus produtores.

Esse movimento caracteriza-se por uma ruptura com as instituições anteriores à década de 1990, posto que no seu âmbito formulavam-se aquelas políticas universais do Estado, que fortaleciam a identidade histórica da universidade e os princípios que dela se originam, que, como vimos, têm sua origem no Estado. O que implica dizer que qualquer política educacional, particularmente para educação superior, não pode ser um instrumento de poder de um governo, ainda que legitimamente eleito.

$\mathrm{O}$ anteriormente exposto mostra a ciência e as instituições de educação superior como resultado de uma política de governo a divulgar o pensamento único, na contramão da dimensão universitária de crítica institucional de seu tempo histórico, e, sobretudo, de seus próprios objetivos. Tal política de governo desconsidera a formação socioistórica e cultural do país, que se acumula no Estado, para o bem ou para o mal. Isso produz profunda modificação na democratização universitária, pois gerida, neste momento, por critérios institucionais mercantis, instituidores da cultura da diferenciação e da concorrência entre as instituições de ensino superior. Como decorrência disso, a gestão das mesmas, conforme se observou durante a década de 1990, sofreu tentativas de transformação sob orientação do paradigma da qualidade total. Destaca-se, ainda, no trabalho acadêmico, a formação dos professores, formação esta em grande parte desprovida de crítica diante do engajamento dessas instituições da educação superior e da ciência e tecnologia em um projeto de governo.

A avaliação, um dos princípios da identidade universitária, põe-se no trabalho acadêmico como síntese, no plano ético, do que até agora se discutiu sobre a educação superior como mercadoria.

A proposta do SINAES, produzida pela Comissão Especial de Avaliação da Educação Superior, orientava-se pela ética que se origina na cultura universitária moderna. No entanto, quando da transformação da proposta em lei, foi repolitizada segundo os objeti- 
vos de controle e regulação da educação superior, colocando, em princípio, em risco o próprio estatuto da autonomia, conseqüentemente, da democratização universitária e de sua gestão.

Para que o interesse público esteja salvaguardado, tanto no sentido de fortalecimento do setor público, como de adequada regulação de sua oferta pela iniciativa privada, seria necessário rediscutir o significado, contraditório com os objetivos declarados deste anteprojeto de lei, do PROUNI, pelo qual os recursos (arrecadáveis) do fundo público são destinados ao fortalecimento das instituições privadas mediante a troca de vagas ociosas pela isenção de impostos. Com os valores não arrecadados, em razão dessa operação, avalia-se que se poderiam garantir muito mais vagas nas instituições federais de ensino superior, com melhor qualidade e a consequiente e necessária valorização da educação superior pública.

O PROUNI, no caso, é um programa decorrente do atual paradigma político de oferta, isto é, tem como base as rubricas do orçamento da União, denominado pelos cientistas políticos de políticas focais, em contraposição às políticas universais. Com características de demandas sociais, essas políticas são reivindicadas pela sociedade civil organizada, com base na cidadania de teor liberal. Essa mudança deve ser posta em relevo, uma vez que altera as relações do indivíduo com a sociedade e desta com o Estado gerencial, produzido em meados dos anos de 1990. Esse programa é um bom exemplo da transformação na educação superior, que afeta os princípios da democratização das suas instituições e sua própria gestão administrativa, financeira e cultural.

A relação público/privado, com especial fortalecimento do pólo público e maior regulação do privado, dá-se também e fundamentalmente pela forma como se organiza e se estrutura o financiamento público da educação superior. Da utilização do fundo público para o setor privado e das leis que a definem não se faz menção no anteprojeto de lei de educação superior, ainda menos de sua eventual revogação. $\mathrm{O}$ mesmo se deve dizer das questões envolvidas pela lei $n^{\circ} 10.973$, de 2/12/2004, sobre a inovação tecnológi- ca, que dispõe sobre incentivos à inovação e à pesquisa científica e tecnológica no ambiente produtivo, e que tenderia a comprometer o estatuto da autonomia universitária, criando condições propícias para a adoção de práticas heterônomas na pesquisa em instituições federais de ensino superior.

O anteprojeto não se pronuncia sobre isso, provavelmente porque essa questão, na divisão de atribuições na estrutura ministerial, está a cargo do Ministério de Ciência e Tecnologia (MCT), ao qual se vinculam e subordinam o Conselho Nacional de Desenvolvimento Científico e Tecnológico (CNPq), os institutos federais de pesquisa, os fundos setoriais e o próprio controle de execução da Lei da Inovação Tecnológica. Pode-se perguntar: que benefícios a divisão de atribuições traz à educação superior como bem público? Como a nova lei tratará, no objetivo de fortalecer o setor público com autonomia, das disposições legais da Lei da Inovação Tecnológica, assim como das disposições introduzidas pela lei no 11.079/04 (das parcerias público/privado), que conduzem a uma clara, contraditória e perversa indiferenciação das esferas pública e privada ${ }^{8} \mathrm{~A}$ democracia universitária, bem como a gestão das instituições de educação superior, o trabalho acadêmico e a avaliação, ficam subordinados, dada a heteronomia proporcionada por essa lei, às demandas do mercado.

Quanto à questão da regulação das instituições de educação superior privadas, especialmente as com fins de lucro, existiriam duas formas de controle da expansão e funcionamento com garantia de qualidade: controle de entrada e controle de saída (Bizzo, 2005). Até hoje se tem privilegiado o controle de saída, muito difícil do ponto de vista prático e especialmente político. O controle de entrada, mais fácil, factível e menos desgastante - porque não credenciar é menos oneroso e traz menores conseqüências do que descredenciar -, deveria ser o caminho adotado.

${ }^{8}$ Ver a definição e a composição do Sistema Federal de Educação Superior, constante do anteprojeto. 
O anteprojeto parece tê-lo adotado, mas o faz ainda em termos insuficientes e eventualmente equivocados. Estabelecer critérios de exigência quanto à qualificação do corpo docente e ao regime de trabalho diferenciados entre instituições organizadas como universidades, centros universitários e faculdades é no mínimo questionável, se os diplomas outorgados deverão ter validade nacional equivalente. Mais: estabelecer que um certo percentual do corpo docente seja portador do título de mestre ou de doutor, sem definição do percentual específico em cada caso, é aceitar a hipótese de que a existência no corpo docente de um único docente doutor satisfaria a norma legal. O mesmo se diga em relação às exigências quanto ao regime de trabalho docente. Isso vale também para a proposta, supostamente garantidora de avanços na democratização e controle das instituições privadas, de que um dos dirigentes das mesmas seja eleito pela comunidade acadêmica.

A questão da autonomia deve ser examinada em conjunto com a questão do financiamento, por se tratar de um binômio inseparável. Trata-se, inicialmente (e já era tempo), da decisão política de reconhecer, não outorgar, a autonomia universitária, no caso, a das instituições federais de educação superior. Sabemos que a autonomia, além de ser uma condição da identidade universitária, sem a qual essa instituição não merece o nome, é atualmente estabelecida pela Constituição Federal de 1988. Passados dezesseis anos de sua promulgação, não gozam ainda as universidades federais de autonomia administrativa e de gestão financeira e patrimonial. O reconhecimento da autonomia nestes termos, para se tornar realidade, depende de garantias financeiras decorrentes do lugar que ocupa a universidade nas políticas públicas de Estado, como visto anteriormente.

Se o montante de recursos financeiros destinados às instituições federais foram reduzidos de $0,91 \%$ do PIB em 1994 para 0,51\% em 2004, não será a subvinculação de $75 \%$ do que resta dos $18 \%$ dos impostos, conforme previsto na Constituição Federal de 1988 - com os descontos provocados por diversas contribuições (Contribuição Provisória sobre Movi- mentação Financeira - CPMF, Contribuição para Financiamento de Seguridade Social - COFINS, entre outros) - que irá recuperar as perdas históricas das instituições federais de educação superior e garantir que elas se expandam e o ensino superior público atinja, em prazo determinado, $40 \%$ das matrículas da educação superior do país.

No que tange ao binômio autonomia/financiamento, cabe ainda destacar a proposta de extinção das fundações de apoio institucional, criadas às centenas como entes privados no interior do espaço público universitário, com a usual justificativa de que a ausência de autonomia administrativa e de gestão financeira das instituições federais de educação superior as tornava imprescindíveis. Bem ou mal, estão cumprindo seu papel, mas, se a proposta de autonomia presente no anteprojeto de fato se efetivar, deveriam perder a razão de ser e deixar de se constituírem em fortalecimento do pólo privado no espaço contraditório da universidade pública, como em muitos casos tem ocorrido.

É, portanto, nesse contexto contraditório que diferentes atores nacionais e internacionais buscam fazer do anteprojeto de lei de educação superior a Lei da Reforma Universitária no Brasil. Com essa estratégia, obscurecem, ao invés de revelarem, as influências que sofre o anteprojeto: da continuidade do tecnicismo, do pragmatismo e dos valores mercantis que passaram a orientar a identidade das instituições de educação superior desde o golpe militar de 1964, especialmente no que se refere à autonomia universitária, à reconfiguração público/privado nas instituições de educação superior (quanto ao seu financiamento, a sua democratização e as formas de gestão), à avaliação, e, sobretudo, ao trabalho acadêmico fundado no princípio da indissociabilidade entre ensino, pesquisa e extensão.

São esses alguns elementos imprescindíveis na análise de um anteprojeto dessa natureza, que orientaram essas reflexões, visando, antes de tudo, a desvelar alguns dos ardis que cercam e condicionam o anteprojeto que, em nova versão, deverá continuar a ser discutido e posteriormente encaminhado 
ao Congresso Nacional. O maior objetivo deste texto foi o de partilhar elementos teórico-analíticos com os sujeitos envolvidos na formulação de políticas públicas, quando, como representantes ou não da sociedade civil organizada, no Parlamento ou fora dele, estão construindo uma nova lei de educação superior.

JOÃO DOS REIS SILVA JUNIOR, doutor em educação pela Pontifícia Universidade Católica de São Paulo (PUC-SP) e pósdoutorado em sociologia política pela Universidade Estadual de Campinas (UNICAMP), atualmente é professor e pesquisador do Departamento de Educação e do Programa de Pós-Graduação em Educação da Universidade Federal de São Carlos (UFSCAR). É autor de diversos livros e muitos artigos e capítulos de livros no Brasil e no exterior. Últimos livros publicados: Novas faces $d a$ educação superior no Brasil: reforma do Estado e mudança na produção, em co-autoria com Valdemar Sguissardi (Bragança Paulista: EDUSF, 1999; Bragança Paulista, São Paulo: EDUSF, Cortez, 2001, $2^{\text {a }}$ edição); Trabalho e formação, em co-autoria com Jorge Luís Camarano González (São Paulo: Xamã, 2001); Reformas do Estado e da educação no Brasil de FHC (São Paulo: Xamã, 2003); O institucional, a organização e a cultura da escola, em co-autoria com Celso Ferretti (São Paulo: Xamã, 2004). E-mail: jr@power.ufscar.br

VALDEMAR SGUISSARDI, doutor em ciências da educação pela Universidade de Paris X-Nanterre (França), é professor titular aposentado da Universidade Federal de São Carlos (UFSCAR) e professor do Programa de Pós-Graduação em Educação da Universidade Metodista de Piracicaba (UNIMEP). Autor ou co-autor de oito livros e várias dezenas de artigos sobre a temática da educação superior, objeto principal de seus estudos e pesquisas. Livros mais recentes: Novas faces da educação superior no Brasil: reforma do Estado e mudança na produção, em co-autoria com João dos Reis Silva Júnior (Bragança Paulista: EDUSF, 1999, e Bragança Paulista, São Paulo: EDUSF, Cortez, 2001, 2ª edição), Educação superior: velhos e novos desafios, organizador e coautor (São Paulo, Xamã, 2000), Educação superior: análises e perspectivas de pesquisa, co-organizador e co-autor (São Paulo, Xamã, 2001).E-mail:vs@merconet.com.br

\section{Referências bibliográficas}

BIZZO, Nélio, (2005). Por que não cadastrar os docentes. Jornal da Ciência, n. 2.700, 2 fev.

BRESSER PEREIRA, Luís Carlos, (1996). Crise econômica e reforma do Estado no Brasil: para uma nova interpretação da América Latina. São Paulo: Editora 34.

CARDOSO, Fernando Henrique, (1993). A construção da democracia: estudos sobre política. São Paulo: Siciliano.

GRAJEW, Oded, (2002). Um pacto pela cidadania. Folha de S.Paulo, São Paulo, 12 nov. Tendências e Debates, p. A3.

GRAU, Eros, (2005). Constituição e reforma universitária. Folha de S.Paulo, São Paulo, 23 jan., p. 3.

LOCKE, John, (1991). Segundo tratado sobre o governo. In: Locke. São Paulo: Abril Cultural (coleção Os pensadores).

MARX, Karl, ENGELS, Friedrich, (s.d.). Manifesto do Partido Comunista. In: MARX, K. Obras escolhidas - v. 1. São Paulo: Alfa-Ômega.

RICCI, Rudá, (2005). Lulismo: três discursos e um estilo. Espaço Acadêmico, n. 45, fev. Disponível em: <http://www. espacoacademico.com.br/045/45ricci.htm>. Acesso em: 6 fev.

SADER, Emir, (2003). Público versus mercantil. Folha de S.Paulo, São Paulo, 19 jun., p. 3.

SCHUGURENSKY, Daniel, (2002). Autonomía, heteronomía, y los dilemas de la educación superior en la transición al siglo XXI: el caso de Canadá. In: RODRIGUEZ GÓMEZ, Roberto (org.). Reformas en los sistemas nacionales de educación superior. La Coruña (Espanha): Netbiblo, p. 109-148.

SGUISSARDI, Valdemar, SILVA JR., João dos Reis, (2001). As novas faces da educação superior no Brasil: reforma do Estado e mudança na produção. São Paulo: Cortez.

SMITH, Adam, (1993). A riqueza das nações - v. 2. Lisboa: Fundação Calouste Gulbenkian.

SIQUEIRA, Ângela de C., (2004). A regulamentação do enfoque comercial no setor educacional via OMC/GATS. Revista Brasileira de Educação, Campinas, nº 26, p. 145-156, maio-ago.

VOGT, Carlos, (2003). Indagações por um novo humanismo: o imperativo da ética num mundo pragmático. Revista Pesquisa, São Paulo, nº 85, p. 58-59, mar.

Recebido em janeiro de 2005 Aprovado em abril de 2005 


\section{Resumos/Abstracts}

João dos Reis Silva Júnior. e Valdemar Sguissardi

A nova lei de educação superior: fortalecimento do setor público e regulação do privado/mercantil ou continuidade da privat ização e mercantilização do público?

Este artigo orienta-se pela compreensão de que uma reforma da educação superior é um processo político de ajuste institucional, com origem no Estado moderno, para a conformação do ser social e de suas atividades, assim como para a produção de uma nova cultura, visando a construir o pacto social requerido por dado tempo histórico. Essas orientações conduzem, de modo específico, à identificação de alguns elementos preliminares para a análise desta atual reforma institucional no Brasil. Portanto, trata-se de algo que ultrapassa um texto jurídico-formal como o anteprojeto de Reforma da Educação Superior de 6 de dezembro de 2004. Destacam-se, dentre os muitos elementos a serem considerados neste texto, algumas categorias e princípios que configuram a identidade universitária na modernidade e aqueles elementos que se referem às mudanças jurídico-administrativas anteriores ao anteprojeto, isto é, os que tomam existência na Lei de Inovação Tecnológica, na que institui o Sistema Nacional de Avaliação da Educação Superior, na que institui o Programa Universidade para Todos, e na que institui as parcerias público/privado. Pretende-se que este texto se constitua numa preparação para análises mais refinadas do projeto de Lei da Educação Superior na versão a ser proximamente discutida no Congresso Nacional.

Palavras-chave: reforma do Estado; reforma da educação superior; avaliação da educação superior; inovação tecnológica; relação público/privado

The new higher education bill: strengthening the public sector and regulating the private/commercial or a continuation of the process of privatisation and commercialisation of the public sector?

This article is oriented by the comprehension that higher education reform is, on the one hand, a political process of institutional adjustment to the conformation of the social being and its activities, originating in the modern State. On the other hand, it seeks to produce a new culture with the goal of constructing the social pact necessary for a given historical moment. These tendencies specifically lead to the identification of some preliminary elements for an analysis of the current institutional reform in Brazil. Therefore, the analysis deals with questions that go beyond a formal legal text like the Higher Education Reform Draft Bill, of $6^{\text {th }}$ December 2004. Among the many elements to be considered in this text certain categories and principles are emphasised which represent the identity of the modern university and those elements which refer to legal-administrative changes prior to the draft bill, that is, those originating from the Law of Technological Innovation, or from the Law that institutes the National Programme of Evaluation in Higher Education, or from the Law that creates the Programme University for All, and, finally, from the Law of the Public/Private Partnerships. The text constitutes a preparation for a more refined analysis of the Higher Education Draft Bill, in the version to be discussed in the National Congress in the near future.

Key-words: State reform; higher education reform; evaluation of higher education; technological innovation; public/private relationship 